\title{
KEMAMPUAN ECENG GONDOK (Eichhornia sp.), KANGKUNG AIR (Ipomea sp.), DAN KAYU APU (Pistia sp.) DALAM MENURUNKAN BAHAN ORGANIK LIMBAH INDUSTRI TAHU (SKALA LABORATORIUM)
}

\author{
Lutfiana Sari Indah, Boedi Hendrarto, Prijadi Soedarsono ${ }^{1}$
}

Program Studi Manajemen Sumberdaya Perairan, Jurusan Perikanan

Fakultas Perikanan dan Ilmu Kelautan, Universitas Diponegoro

\begin{abstract}
ABSTRAK
Limbah tahu mengandung bahan organik yang tinggi, dikarenakan bahan baku pembuatan tahu (kedelai) mengandung protein hingga $40-60 \%$. Bila limbah cair tahu langsung dibuang ke sungai akan menyebabkan pencemaran, merusak habitat biota serta mengurangi estetika. Salah satu upaya yang mudah, murah dan aplikatif untuk mengurangi dampak tersebut adalah secara fitoremediasi menggunakan tanaman. Penelitian ini bertujuan untuk mengetahui perlakuan terbaik dalam menurunkan kandungan bahan organik limbah tahu dengan menggunakan tanaman eceng gondok (Eichhornia sp.), kangkung air (Ipomea sp.) dan kayu apu (Pistia sp.), serta mengetahui kondisi fisik tanaman dan air yang dilihat dari nilai hue.

Metode yang digunakan adalah eksperimen skala laboratorium dengan menggunakan wadah percobaan berupa ember bervolume $15 \mathrm{~L}$ yang diisi dengan limbah tahu dengan konsentrasi $25 \%$ sebanyak $10 \mathrm{~L}$. Variabel utama penelitian adalah kandungan bahan organik pada media percobaan yang didukung dengan berat basah tanaman, nilai hue air dan daun serta kualitas air ( $\mathrm{pH}$ dan suhu). Rancangan percobaan adalah RBD (Randomize Block Design) dengan 2 perlakuan dan 4 kali ulangan. Perlakuan pertama jenis tanaman (eceng gondok, kangkung air dan kayu apu), perlakuan kedua sebagai blok adalah waktu (hari ke-7, ke-14, ke-21 dan ke-28). Data bahan organik dianalisis dengan Analysis of Variant (Anova) dan uji lanjut BNT (Beda Nyata Terkecil) dengan taraf signifikan 95\%. Hasil penelitian menunjukkan bahwa eceng gondok (Eichhornia sp.) memberikan hasil terbaik dalam menurunkan bahan organik limbah tahu hingga menjadi $195 \pm 48.61 \mathrm{mg} / \mathrm{l}$ dengan daun masih tampak hijau dan warna air coklat bening.
\end{abstract}

Kata kunci: Eceng Gondok, Kangkung Air, Kayu Apu, Bahan Organik, Limbah Tahu

\section{ABSTRACT}

Soya waste contains high organic matter, because the raw material used to making soya (soybean) containing protein to $40-60 \%$. If soya waste thrown away directly to the river would cause water pollution, destroy the habitat of aquatic biota and reduces aesthetics. One of the easy efforts to reduce the impact is using plants or phytoremediation. The aim of this research was to know the best treatment to decrease organic matter of soya waste by water hyacinth (Eichhornia sp.), water spinach (Ipomea sp.) and water lettuce (Pistia sp.) and to know the change of physical condition of plants and water by hue value.

The method of this research was laboratory experiment scale used basin with $15 \mathrm{~L}$ volume and filled with $25 \%$ of soya waste as much as $10 \mathrm{~L}$. The main variable was organic matter in water experiment and the supported varibel were the heavy wetness, hue value of leaf and water, $\mathrm{pH}$ and temperature. The experiment design was Randomized Block Design with 2 treatment and 4 replications. The first treatment was variety of plants (water hyacinth, water spinach and water lettuce), the second treatment as block treatment was the time (the $7^{\text {th }}$ day, $14^{\text {th }}$ day, $21^{\text {st }}$ day and $28^{\text {th }}$ day). The data of organic matter analyzed by Analisis of variant (Anova) and post hoc test LSD (Least Significant Differences) with 95\% significant. The result showed that water hyacinth was the best treatment in decreasing organik matter soya waste until $195 \pm 48.61 \mathrm{mg} / \mathrm{l}$ with the greeny leaf and browny transparant of water.

Key word : Water Hyacinth, Water Spinach, Water Lettuce, Organic Matter, Soya Waste

*) Penulis Penanggung Jawab 


\section{Pendahuluan}

Tahu merupakan makanan yang banyak disukai oleh masyarakat tidak hanya di Indonesia tetapi di negara Asia lainnya. Selain rasanya enak, bergizi, proses pembuatan tahu pun terbilang mudah. Berdasarkan info dari Agrojateng (2010), potensi IKM Kab. Semarang untuk industri tahu skala menengah hanya berjumlah 3 dan skala kecil berjumlah 74 . Hal ini menunjukkan bahwa industri tahu di Jawa Tengah didominasi oleh usaha-usaha skala kecil dengan modal < Rp 200 juta. Industri kecil dan menengah dikarakteristikkan sebagai industri dengan tingkat efisien energi rendah dan tingkat pencemaran yang tinggi dikarenakan kurang atau tidak adanya sistem penanganan limbah yang baik.

Limbah tahu terdiri dari 2 jenis, yaitu limbah padat dan cair (Kaswinarni, 2007). Limbah padat dapat digunakan sebagai pakan ternak sedangkan limbah cair biasanya langsung dialirkan ke badan air tanpa ada pengolahan terlebih dahulu. Hal ini tentu saja akan mencemari perairan melihat sifat limbah cair yaitu mengandung zat-zat organik terlarut yang tinggi dan akan membusuk jika dibiarkan tergenang sampai beberapa hari di tempat terbuka (Sarwono dkk, 2004). Limbah tahu menghasilkan kadar BOD yang tinggi sebesar 3469,8 mg/l (Istikomah et al., 2007). Berdasarkan tingginya nilai BOD di atas bahwa limbah cair industri tahu mengandung bahan organik tinggi, bila dibuang ke badan air tanpa pengolahan terlebih dahulu akan berisiko mencemari perairan. Pengaruh utama limbah organik yang masuk ke dalam air adalah menurunkan kandungan oksigen terlarut dan meningkatkan BOD, COD, TSS dan TDS yang merupakan parameter utama pencemaran perairan (Lestari, 2008). Menurut Sugiharto (1987) dalam Mulyani (2012), jika bahan organik berkonsentrasi tinggi yang belum diolah dibuang ke badan air, maka bakteri akan menggunakan oksigen terlarut dalam air untuk proses pembusukannya sehingga dapat mematikan kehidupan dan menimbulkan bau busuk dalam air. Hal ini tentu saja akan mempengaruhi kehidupan organisme di perairan. Daerah Sidorejo, Kota Salatiga masih ada beberapa industri kecil tahu yang membuang limbah cair langsung ke badan air. Sehingga diperlukan upaya pengolahan limbah yang murah, mudah dan aplikatif, salah satunya dengan proses biologi yaitu fitoremediasi.

Fitoremediasi adalah sebuah teknologi yang menggunakan berbagai tanaman untuk menurunkan, mengekstrak atau menghilangkan kontaminan dari tanah dan air (EPA, 2000). Tanaman air berperan sebagai aerator perairan melalui proses fotosintesis, mengatur aliran air, membersihkan aliran tercemar melalui proses sedimentasi serta penyerapan partikel dan mineral. Di Kota Salatiga banyak sekali dijumpai tanaman air, terutama di daerah yang berbatasan dengan Rawapening, diantaranya eceng gondok (Eichhornia sp.), kayambang (Salvinia sp.), kayu apu (Pistia sp.), kangkung air (Ipomea sp.), genjer (Limnocharis sp.) dan lain sebagainya. Melihat kondisi ini, penulis mencoba melakukan penelitian dengan memanfaatkan sumberdaya yang ada di Kota Salatiga yaitu menggunakan berbagai jenis tanaman air untuk meminimalisir pencemaran perairan yang terjadi akibat limbah cair tahu yang langsung dibuang ke badan air tanpa pengolahan terlebih dahulu. Metode fitoremediasi ini terbilang mudah, murah, dan efisien bila diaplikasikan oleh industri skala kecil dan menengah.

\section{Materi dan Metode Penelitian}

\section{A. Materi Penelitian}

Variabel penelitian terdiri dari dua (2) variabel yaitu variabel utama dan variabel penunjang. Variabel utama adalah kandungan bahan organik pada media penelitian. Variabel penunjang meliputi berat basah tanaman, hue air, hue daun, $\mathrm{pH}$ dan suhu air. Materi yang dibutuhkan adalah limbah cair industri tahu skala rumah tangga yang bertempat di Salatiga. Tanaman air (eceng gondok, kangkung air dan kayu apu) dengan berat $\pm 300 \mathrm{~g}$ (Hermawati et al., 2005) dan berkondisi fisik yang bagus (organ tubuh lengkap dan tidak cacat).

\section{B. Metode Penelitian}

Sesuai dengan tujuan dari penelitian ini yaitu untuk mengetahui kemampuan penyerapan terbaik dari ketiga tanaman uji dalam menurunkan kandungan organik limbah tahu dan untuk membuktikan hipotesis, maka metode yang digunakan adalah metode eksperimen skala laboratorium.

Penelitian ini dilakukan dengan 2 tahap, uji pendahuluan dan penelitian utama. Uji pendahuluan dilakukan untuk menentukan konsentrasi dan lama waktu yang akan digunakan pada penelitian utama. Rancangan percobaan yang digunakan adalah Randomized Block Design dengan 2 perlakuan yaitu jenis tanaman (eceng gondok, kangkung air dan kayu apu) dan waktu (hari ke-7, 14, 21, 28) dengan 4 kali ulangan. Uji Pendahuluan

Pengenceran limbah tahu yang digunakan adalah 100\%, 75\%, 50\% dan 25\% dengan menambahkan air PDAM hingga wadah terisi air sebanyak $10 \mathrm{~L}$. Tanaman uji dimasukkan ke dalam media percobaan. Pada wadah diberikan aerasi untuk mencegah pengendapan pada dasar wadah percobaan. Pengamatan ini dilakukan hingga 14 hari. Berdasarkan hasil uji pendahuluan, maka konsentrasi $25 \%$ ditentukan sebagai konsentrasi pada penelitian utama selama 28 hari. 


\section{Penelitian Utama}

Ketiga tanaman uji dilakukan aklimatisasi selama 1 minggu. Sebelum dimasukkan ke dalam wadah ditimbang terlebih dahulu $\pm 300 \mathrm{~g}$ dengan umur kira-kira 1 bulan. Sebelum perlakuan diukur terlebih dahulu $\mathrm{pH}$, suhu, nilai hue dan kandungan bahan organik pada air media percobaan. Kemudian pH, suhu, nilai hue daun dan hue air dilakukan setiap hari. Berat basah tanaman dan kandungan bahan organik dilakukan setiap 7 hari selama 28 hari. Kandungan bahan organik dianalisa dengan uji anova dan uji lanjut Beda Nyata Terkecil (BNT), sedangkan berat basah tanaman, suhu, $\mathrm{pH}$ serta nilai hue dianalisis secara deskriptif.

\section{Hasil dan Pembahasan}

Berat Basah Tanaman

Gambaran tentang kecenderungan perubahan dengan berjalannya waktu tersaji pada Gambar 1 .

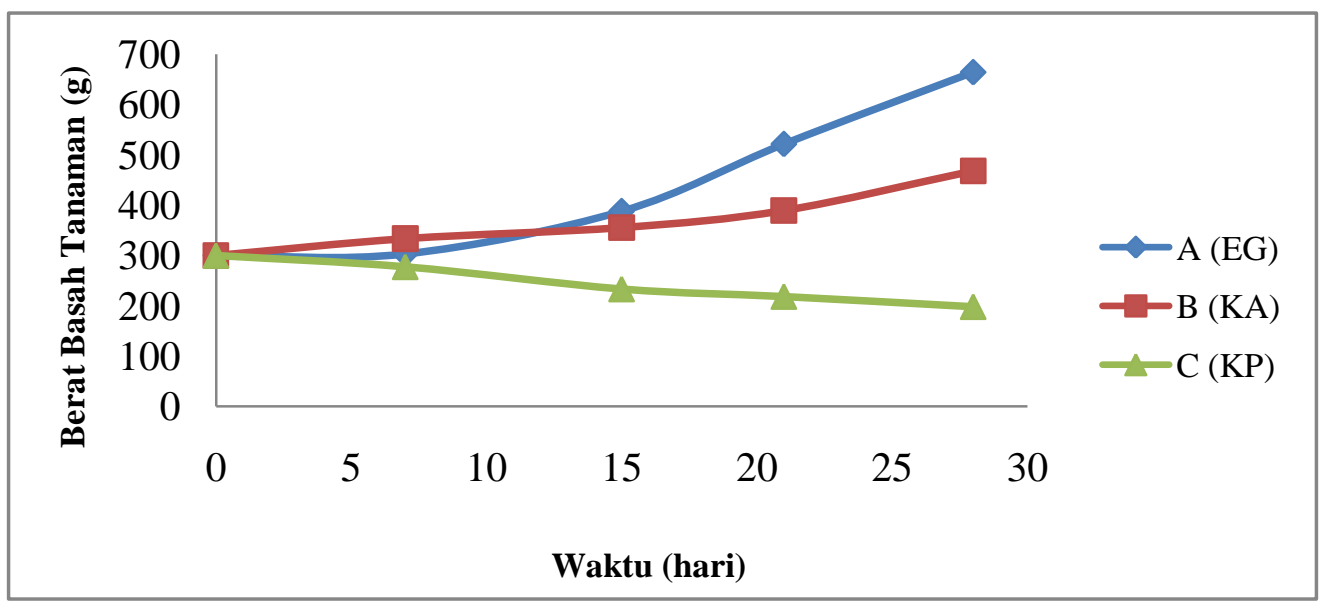

Gambar 1. Grafik Rerata Berat Basah Tanaman Uji Selama 28 Hari

Tanaman eceng gondok (EG) dan kangkung air (KA) mengalami kenaikan berat basah hingga hari ke28. Namun tanaman kayu apu (KP) justru mengalami penurunan berat basah hingga hari ke-28 menjadi $198 \pm 52.24$ g. Peningkatan berat basah ini diduga karena akar-akar tanaman mampu menyerap dengan baik bahan organik yang mengandung nutrisi dan menyimpannya ke dalam jaringan vaskular tanaman untuk proses metabolisme dan digunakan untuk memperbanyak sel. Bahan organik yang ada dimanfaatkan sebagai nutrient yang dibutuhkan untuk pertumbuhan tanaman air (Sugiarti, 2002). Pertumbuhan eceng gondok (Eichhornia sp.) selama penelitian (28 hari) lebih pesat dibandingkan tanaman lainnya diduga karena eceng gondok memiliki kemampuan yang luar biasa dalam menyerap nutrisi dan zat-zat lainnya. Eceng gondok dapat tumbuh dengan cepat dua kali lipat pada kondisi yang sesuai setiap 11 - 18 hari (Coetzee et al., 2009). Tanaman eceng gondok mengalami peningkatan berat basah diduga karena air yang digunakan dalam pengujian mengandung unsur hara yang diperlukan untuk pertumbuhan eceng gondok, seperti, $\mathrm{N}$ dan $\mathrm{P}$ (Rahmaningsih, 2006).

Kayu apu (Pistia sp.) justru mengalami penurunan berat basah hingga hari ke-28. Penurunan ini diduga karena kemampuan menyerap bahan organik yang sangat besar di awal sehingga menyebabkan daun kayu apu menjadi layu (Chun, 2007). Kemudian semakin hari tanaman asli atau tanaman utama mati diduga karena kurang bisa beradaptasi dengan kondisi media namun terdapat tunas-tunas baru yang berasal dari stolon. Hal ini dikarenakan kayu apu juga bisa berkembangbiak dengan stolonnya. Stolon ini mudah sekali terpotong dan pada bagian ujungnya dapat tumbuh menjadi individu baru (Sastrapradja dan Bimantoro (1981) dalam Safitri, 2009). Hal itulah yang menyebabkan berat basah tanaman kayu apu menurun selama penelitian. Dari pemaparan di atas, dapat disimpulkan bahwa eceng gondok memiliki berat basah tertinggi dikarenakan tanaman eceng gondok mampu memanfaatkan bahan organik yang ada untuk proses metabolisme dan perbanyakan sel. 
Kandungan Bahan Organik Media Percobaan

Gambaran tentang kecenderungan perubahan dengan berjalannya waktu tersaji pada Gambar 2.

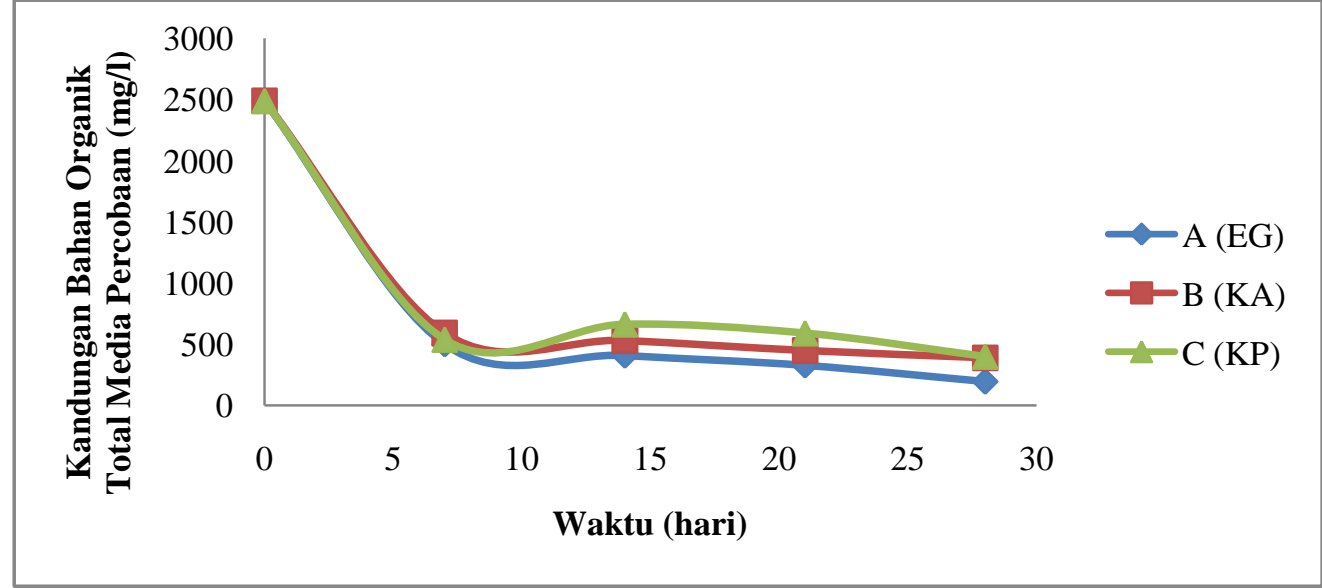

Gambar 2. Grafik Kandungan Bahan Organik Media Percobaan Per 7 Hari Selama 28 Hari

Perlakuan A (eceng gondok), B (kangkung) dan C (kayu apu) mampu menurunkan kandungan bahan organik pada media percobaan. Tanaman eceng gondok, kangkung air, kayu apu mampu menyerap bahan organik berturut-turut hingga tersisa $195 \pm 48.61 \mathrm{mg} / \mathrm{l}, 388.50 \pm 90.22 \mathrm{mg} / \mathrm{l} \mathrm{dan} 400 \pm 98.89 \mathrm{mg} / \mathrm{l}$. Perlakuan A dengan menggunakan eceng gondok (Eichhornia sp.) memberikan hasil yang memuaskan sebagai agen fitoremediasi. Eceng gondok memiliki struktur tubuh yang mendukung untuk mempengaruhi kemampuan dalam penyerapan bahan-bahan organik maupun zat-zat lain dalam air. Eceng gondok memiliki lubang stomata yang besar, yaitu dua kali lebih besar dibandingkan dengan kebanyakan tanaman lain dan jarak antar stomata adalah delapan kali besarnya lubang (Penfound dan Earle (1948) dalam Rahmaningsih, 2006). Kemampuan eceng gondok dalam penyerapan juga diduga karena adanya vakuola dalam struktur sel. Adanya bahan-bahan yang diserap menyebabkan vakuola menggelembung dan mendorong sitoplasma ke pinggiran sel sehingga protoplasma semakin dekat dengan permukaan sel. Hal ini menyebabkan pertukaran atau penyerapan bahan antara sel dengan sekelilingnya menjadi lebih efisien (Rahmaningsih, 2006).

Perlakuan B menggunakan kangkung (Ipomea sp.) memberikan hasil yang sama positif. Kangkung diduga mampu beradaptasi dengan baik, mampu memanfaatkan nutrisi yang terdapat pada bahan organik media percobaan untuk tumbuh dan berkembang. Perlakuan C menggunakan kayu apu (Pistia sp.) juga memberikan hasil yang baik dalam penyerapan bahan organik hingga hari ke-28. Namun, pada hari ke-14 kandungan bahan organik pada kayu apu mengalami peningkatan menjadi $664 \mathrm{mg} / \mathrm{l}$. Hal ini diduga karena besarnya penyerapan bahan organik pada awal penelitian sehingga kayu apu mulai terlihat layu dan kemampuan untuk menyerap bahan organik berkurang. Selanjutnya kayu apu mampu beradaptasi dengan baik yang dicirikan dengan menurunnya kandungan bahan organik dan munculnya tunas-tunas baru yang berasal dari stolonnya. Penyerapan bahan organik pada tanaman juga diduga dipengaruhi oleh adanya mikroba rhizosfera yang terdapat pada akar tanaman yang mampu menguraikan bahan organik maupun anorganik (Suriawiria, 2003).

\section{Nilai Hue Air}

Gambaran perubahan nilai hue air pada tanaman uji selama 28 hari penelitian tersaji pada Gambar 3.

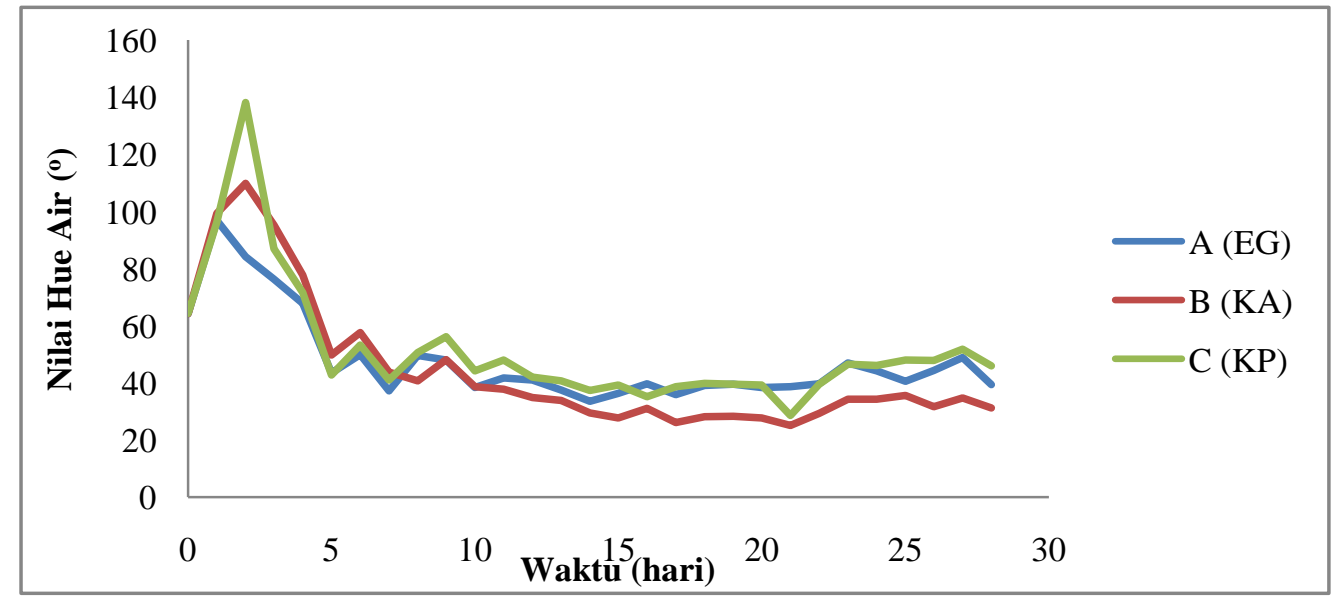

Gambar 3. Grafik Nilai Hue Air Media Percobaan Selama Penelitian 
Nilai hue air pada awal percobaan sebesar $64.25^{\circ}$ menunjukkan warna putih keruh. Setelah 28 hari ketiga perlakuan menunjukkan hasil yang sama, yaitu dapat menjernihkan atau menstabilkan warna air, yang ditandai dengan menurunnya nilai hue. Warna air menjadi coklat bening seperti warna teh, dengan kisaran nilai hue sebesar $30^{\circ}-50^{\circ}$. Dapat diasumsikan bahwa tanaman eceng gondok, kangkung air dan kayu apu memang bisa digunakan sebagai biofilter terhadap limbah organik (dalam hal ini limbah tahu).

\section{Nilai Hue Daun}

Gambaran perubahan nilai hue daun pada tanaman uji selama penelitian 28 hari disajikan pada Gambar 4

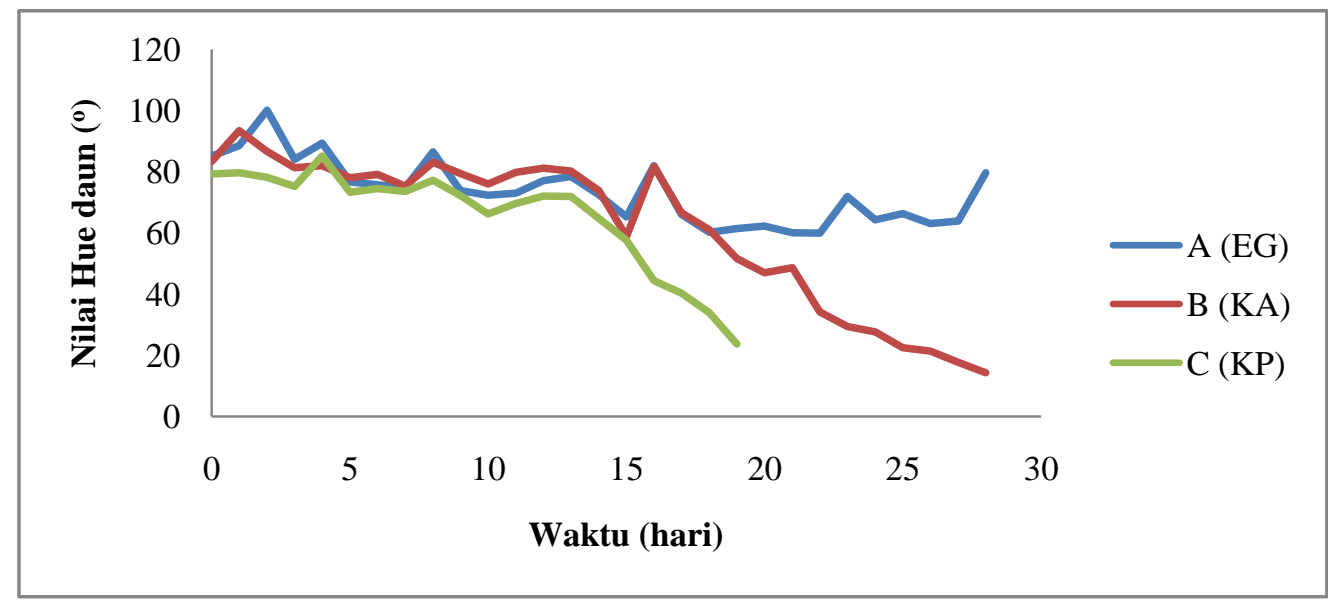

Gambar 4. Grafik Nilai Hue Daun Tanaman Uji Selama Penelitian

Berdasarkan Gambar 4 dapat dikatakan bahwa nilai hue daun cenderung menurun selama penelitian. Nilai hue daun pada hari ke-0 menunjukkan warna hijau dengan kisaran skala $70^{\circ}-100^{\circ}$. Semakin hari nilai hue daun semakin menurun ditandai dengan warna daun yang tidak terlihat cerah. Hue daun bisa mengindikasikan tingkat kesehatan daun yang terlihat dari kandungan klorofil yang nantinya akan digunakan untuk proses fotosintesis. Semakin hijau warna daun, kandungan klorofil semakin banyak dan diharapkan proses fotosintesis semakin optimal untuk pertumbuhan tanaman. Dari ketiga tanaman uji, daun kayu apu lebih dahulu terlihat kuning. Hal ini terlihat pada hari ke-10, nilai hue kayu apu sudah berada pada $66^{\circ}$ yang termasuk dalam skala warna kuning. Daun kayu apu diduga sudah mulai mengalami titik jenuh bahkan ada yang layu dan mati disebabkan akumulasi dari bahan organik yang terserap oleh tanaman tersebut (Chun, 2007). Kemampuan menyerap bahan organik yang besar ketika di awal (pada hari ke-7) diduga menyebabkan kayu apu berada dalam titik jenuh. Inilah yang menyebabkan sampel daun dari kayu apu telah mati pada hari ke-20 dikarenakan ketidaktahanan dari daun tersebut akan bahan organik yang berlebih. Begitu juga dengan kangkung air yang mengalami penurunan nilai hue daun hingga hari ke-28 mencapai $27.63^{\circ}$ dengan warna kuning kecoklatan.

Warna daun eceng gondok tetap berwarna hijau hingga akhir penelitian dengan nilai hue $79.63^{\circ}$. Diduga permukaan daun eceng gondok dipenuhi oleh stomata yang berukuran besar sehingga memiliki laju fotosintesis yang tinggi (Ahmad (2008) dalam Widyaningsih, 2012), sehingga warna daun eceng gondok masih terlihat hijau hingga hari ke-28. Hal ini membuktikan bahwa tanaman eceng gondok mampu beradaptasi dan menyerap dengan baik kandungan bahan organik pada limbah tahu yang kemudian bahan organik tersebut dimanfaatkan secara optimal untuk berfotosintesis.

\section{pH dan Suhu Air Media Percobaan}

pH air selama penelitian berkisar antara $4-8$. Limbah tahu bersifat asam diduga karena bahan pembuatan tahu adalah kedelai, dimana pada pembuatannya dilakukan penambahan asam cuka (Agung dan Hanry, 2009). Suhu sekitar $21-25.5^{\circ} \mathrm{C}$, kisaran suhu tersebut masih dapat ditolerir oleh ketiga tanaman uji. Eceng gondok tumbuh optimal pada suhu $27^{\circ}-30{ }^{\circ} \mathrm{C}$ (Gopal (1987) dalam Coetzee et al., 2009), kayu apu dapat mentolerir suhu $15^{\circ}-35{ }^{\circ} \mathrm{C}$ (Pieterse (1981) dalam Neuenschwander et al., 2009), namun lebih optimal pertumbuhannya pada suhu $22^{\circ}-30^{\circ} \mathrm{C}$, kangkung air suhu optimum $25^{\circ}-30^{\circ} \mathrm{C}$ (Rukmana, 2000).

\section{Kesimpulan}

Hasil penelitian dari ketiga tanaman air eceng gondok, kangkung air, dan kayu apu selama 28 hari maka perlakuan fitoremediasi terbaik adalah dengan menggunakan tanaman eceng gondok (Eichhornia sp.). 


\section{Ucapan Terima Kasih}

Ucapan terima kasih ditujukan kepada Ibu Merry selaku pembimbing lapangan dari Kantor Lingkungan Hidup Kota Salatiga. Bapak Junaidi selaku pemilik industri tahu. Ir. Prijadi Soedarsono, M.Sc, Drs. Ign. Boedi Hendrarto, M.Sc, Ph.D atas bimbingannya dalam penyusunan laporan penelitian ini.

\section{Daftar Pustaka}

EPA. 2000. Introduction to Phytoremediation. National Risk Management Research Laboratory Office of Research and Development. U.S. Environmental Protection Agency. Ohio.

Chun, A. 2007. Pemanfaatan Kiapu (Pistia stratiotes) Dalam Remidiasi Kualitas Effluent IPAL PT. Djarum - Kudus (Skala Laboratorium). [Skripsi]. Universitas Diponegoro. Semarang.

Coetzee, J. A.; M. P. Phill.; M. H. Julien; T. D. Center dan H. A. Cordo. 2009. 11. Eichhornia crassipes (Mart.) Solm-Laub. (Pontederiaceae)

Hermawati, E., Wiryanto, dan Solichatun. 2005. Fitoremediasi Limbah Detergen Menggunakan Kayu Apu (Pistia stratiotes L.) dan Genjer (Limnocharis flava L.). Surakarta.

Istikomah, Sulistiyani dan U. Nurullita. 2007. The Difference Of Biochemical Oxygen Demand (BOD) rate Of Soybean Curd Waste Water based On Thick Of River Stone As Trickling Filter Media. UMS. Semarang.

Kaswinarni, F. 2007. Kajian Teknis Pengolahan Limbah Padat Dan Cair Industri Tahu. Universitas Diponegoro. Semarang.

Lestari. 2008. Pembuatan Nata De Coco dari Air Kelapa. [online]. http://lestarimandiri.org/id/homeindustri/86-home-industri/172-pembuatan-nata-de-coco-dari-airkelapa.html

Mulyani, O. 2007. Studi Perbandingan Tanaman Eceng Gondok (Eichhornia crassipes) Sebagai PreTreatment Pengolahan Air Minum Pada Air selokan Mataram. [Skripsi]. UII. Yogyakarta.

Neuenschwander, P., M. H. Julien; T. D. Center dan M. P. Phill. 2009. 17. Pistia stratiotes L. (Araceae).

Rahmaningsih, H. D. 2006. Kajian Penggunaan Eceng Gondok (Eichhormia crassipes) Pada Penurunan Senyawa Nitrogen Efluen Pengolahan Limbah Cair PT. Capsugel Indonesia. [Skripsi]. Institut Pertanian Bogor. Bogor.

Rukmana, R. 2000. Seri Budidaya Kangkung. Bandung: Kanisius.

Safitri, R. 2009. Phytoremediation Greywater Dengan Tanaman Kayu Apu (Pistia stratiotes) dan Tanaman Kiambang (Salvinia molesta) Serta Pemanfaatannya Untuk Tanaman Selada (Lactua sativa) Secara Hidroponik. Institut Pertanian Bogor. Bogor.

Sarwono. 2004. Membuat Aneka Tahu. Jakarta: Penebar Swadaya Diakses pada 18 Agustus 2013 pukul 10.00 WIB.

Sugiarti, S. D. T. S. E. 2002. Kandungan Bahan Organik Di Situ Perikanan, Kampus IPB Dramaga, Bogor. Institut Pertanian Bogor. Bogor.

Suriawiria, U. 2003. Mikrobiologi Air dan Dasar-dasar Pengolahan Buangan Secara Biologis. Alumni. Bandung.

Widyaningsih. 2012. Pengaruh Variasi Biomassa Eceng Gondok (Eichhornia crassipes) Terhadap Kandungan Krom (Cr) Limbah Cair Industri Sablon "Temenan" Monjali Yogjakarta. Universitas Negeri Yogyakarta. Yogyakarta. 